\title{
PEMANFAATAN DAN PENGELOLAAN SITU PANJALU Di CIAMIS, JAWA BARAT
}

\author{
*Zahri Nasution dan Bayu Vita Indah Yanti \\ Balai Besar Penelitian Sosial Ekonomi Kelautan dan Perikanan \\ Gedung Balitbang KP I Lt. 4 \\ Jalan Pasir Putih Nomor 1 Ancol Timur, Jakarta Utara \\ Telp: (021) 64711583 Fax: 64700924 \\ *e-mail: zahri_nas@yahoo.com \\ Diterima 10 Februari 2014- Disetujui 2 Nopember 2014
}

\begin{abstract}
ABSTRAK
Situ Panjalu merupakan situ alam yang dimanfaatkan untuk penangkapan ikan oleh masyarakat sekitar. Alat tangkap yang digunakan berupa alat tangkap jala tebar, gill net, sirib (anco) dan pancing. Ikan yang tertangkap sebagian dibudidayakan di karamba jaring apung (KJA). Situ Panjalu juga dimanfaatkan sebagai kawasan wisata budaya dengan memanfaatkan Nusa Gede sebagai lokasi ziarah. Meskipun pengelolaan Situ Panjalu untuk perikanan belum diatur secara formal. Pengaturan terkait dengan penggunaan alat tangkap, mesh size dan kawasan restocking dilakukan secara informal melalui himbauan dari aparat desa. Sementara itu, pemerintah desa dan Yayasan Borosngora yang mempunyai wewenang mengelola Situ Panjalu masih sebatas pada pengaturan kegiatan pariwisata.
\end{abstract}

Kata kunci: Permasalahan, pengelolaan, perairan situ

\section{Abstract : Utilization And Management of Situ Panjalu Ciamis, West Java by: Zahri Nasution dan Bayu Vita Indah Yanti}

Situ Panjalu is a pool of natural water that it can be used for fishing by the local community. Fishing gear used to catch fish cast net, gill net, sirib (anco) and a fishing pole. Most of the fish were caught cultivated in floating net (KJA). Situ Panjalu also be used as a cultural tourism area, by utilizing Nusa Gede as a pilgrimage site. Although Situ Panjalu to fisheries management has not formally regulated. Arrangements relating to the use of fishing gear, mesh size and area of restocking has been done informally through appeals of village officials. Meanwhile, the village government and the Foundation Borosngora who have the authority to manage Situ Panjalu still limited to regulation of tourism activities.

Keywords : utilization, management, there waters

\section{PENDAHULUAN}

Ketergantungan manusia terhadap sumber daya alam merupakan bagian dari hukum alam, karena sumber daya alam tersebut dimanfaatkan untuk memenuhi kebutuhan hidup manusia. Ketergantungan tersebut memberikan konsekuensi berupa tanggung jawab kepada manusia untuk menjaga kelestarian sumber daya alam (SDA) jika menginginkan keberlanjutan pemanfaatannya. Manusia menjadi kunci perubahan di lingkungannya karena mampu mempengaruhi kelangsungan hidup seluruh makhluk yang ada melalui hubungan timbal-balik yang seimbang dan tidak saling merusak. Situ Panjalu secara turun temurun menjadi sumber kehidupan masyarakat di sekitarnya. Ada 4 (empat) dusun dari 10 (sepuluh) dusun di Desa Panjalu, yaitu Dusun Dukuh, Dusun Balandongan, Dusun Banjarwaru dan Dusun Cukang Padung, yang memanfaatkan sektor perikanan dengan persentasi 75\% dimanfaatkan oleh warga Dusun Dukuh dan 25\% gabungan dari warga Dusun Balandongan, Dusun Banjarwaru dan Dusun Cukang Padung.

Pemanfaatan perikanan di Situ Panjalu dapat dilihat dari adanya aktifitas penangkapan ikan dengan menggunakan alat tangkap jala tebar, gill net, sirib (anco) dan pancing. Disamping itu, beberapa warga juga melakukan usaha pembesaran ikan dengan menggunakan keramba jaring untuk pembesaran ikanikan kecil yang tertangkap, seperti Ikan nila, golsom, keril, betok, beunteur, sepat dan lainnya yang tertangkap oleh anco. Tujuan penelitian ini adalah untuk mengetahui peran masyarakat adat di sekitar situ Panjalu atau terhadap pengelolaan perairan umum di Situ Panjalu.

Berdasarkan uraian tersebut di atas, tulisan ini akan membahas mengenai peran masyarakat dalam pengelolaan Situ Panjalu. Pembahasan mengenai hal ini dianggap menarik, mengingat keberadaan situ alam di Desa Panjalu merupakan kawasan sumber daya perairan dan menjadi sumber mata pencaharian masyarakat setempat.

\section{METODE PENELITIAN}

Tulisan ini dilakukan berdasarkan pada hasil penelitian Peran Masyarakat Adat dalam Pengelolaan Sumber Daya Perikanan Perairan Umum. Penelitian dilakukan pada tahun 2010 di wilayah Situ Panjalu yang juga dikenal sebagai Situ Lengkong, Desa Panjalu, 
Kabupaten Ciamis, Jawa Barat. Metode penelitian yang dilakukan merupakan metode penelitian kualitatif dengan menggunakan survey dan wawancara berdasarkan topik data yang dibuat sebagai alat pengumpulan data. (BBRSEKP, 2010).

\section{HASIL DAN PEMBAHASAN}

\section{Pandangan Mengenai Situ Panjalu}

Ekosistem terbentuk oleh variasi komponen lingkungan di suatu tempat yang berinteraksi membentuk suatu kesatuan yang teratur dengan fungsi dan keadaan lingkungan khas (niche) tertentu (Soemarwoto, 1997). Selama masing-masing komponen berfungsi dengan baik, ekosistem akan berada dalam keteraturan dan keseimbangan yang dinamis. Manusia sebagai subsistem lingkungan selalu berinteraksi dengan lingkungan untuk menjaga dan meningkatkan kualitas hidupnya.

Konsep pelestarian lingkungan modern mesti berisikan upaya pemanfaatan lingkungan sekaligus memelihara keberlanjutannya. Pandangan tersebut melihat pada kondisi jika daya tampung lingkungan dilampaui, maka struktur dan fungsi dasar ekosistem penunjang kehidupan juga akan rusak dan keberlanjutan fungsi lingkungan akan terganggu (Sugandhy, 1999). Pandangan bahwa manusia merupakan bagian dari alam dan sistem kepercayaan yang menekankan penghormatan terhadap lingkungan merupakan nilai yang sangat positif untuk pelestarian lingkungan dalam konsep pembangunan berkelanjutan. Pada prinsipnya pola hubungan manusia pada kawasan tepian badan perairan berdasarkan pada hubungan saling ketergantungan bersifat interaktif dan fungsional. Keberadaan badan perairan seperti sungai, danau, rawa dan laut tidak hanya dieksploitasi tapi juga harus dipelihara dan dipertahankan agar tetap dapat berfungsi (berkelanjutan).

Perilaku sosial dalam kaitannya dengan lingkungan paling tidak terdiri dari dua dimensi, yaitu: bagaimana karakteristik dan kualitas lingkungan mempengaruhi perilaku sosial tertentu, dan bagaimana perilaku sosial tertentu mempengaruhi karakteristik dan kualitas lingkungan. Dimensi yang pertama selalu terjadi pada masyarakat tradisional, dimana terdapat ketergantungan yang tinggi terhadap perubahan lingkungan alam. Dimensi yang kedua biasanya terjadi pada masyarakat modern, karena penguasaan pengetahuan teknologi yang tinggi telah memunculkan bahwa manusia mampu mengatur dan mengendalikan kondisi lingkungan.

Rendahnya pengetahuan dan kesederhanaan teknologi pada masyarakat tradisional berkorelasi dengan perilaku, kebiasan, norma, dan kelembagaan yang sangat memperhatikan kelestarian lingkungan. Kerusakan dan perubahan karakteristik dan kualitas lingkungan akan sangat mempengaruhi sistem sosial, ekonomi, dan budaya mereka. Ketidakmampuan masyarakat tradisional pada sisi lain merupakan kearifan tersendiri terhadap lingkungan yang sudah sangat terganggu ahir-akhir ini.

Selalu terjadi kesulitan dalam menentukan bentuk sistem sosial ekonomi, budaya hukum dan politik pada masyarakat yang sedang mengalami pergeseran dari masyarakat tradisional menuju masyarakat modern. Dualisme antara cara-cara tradisional dan cara-cara modern yang berkembang dalam tipe masyarakat seperti ini, membutuhkan kerja keras dalam merumuskan pola yang paling tepat untuk menjawab permasalahan sosial.

Situ Panjalu atau dikenal juga sebagai Situ Lengkong merupakan sebuah situ alam yang terletak di Desa Panjalu, Kecamatan Panjalu Kabupaten Ciamis Provinsi Jawa Barat. Situ Panjalu memiliki luas 57,95 $\mathrm{Ha}$, di tengah situ terdapat sebuah pulau yang bernama Nusa Gede yang memiliki luas 67,2 Ha. Pulau Nusa Gede dikenal sebagai pulau tempat pusat kerajaan Panjalu yang merupakan leluhur masyarakat Desa Panjalu, dan di tempat ini terdapat makam penyebar ajaran agama Islam yang disebut Mbah Panjalu. Saat ini, Pulau Nusa Gede dikenal juga sebagai kawasan Cagar Alam Nusa Gede dan ditetapkan menjadi salah satu kawasan hutan konservasi dibawah pengawasan Konservasi Sumber Daya Alam (KSDA) wilayah VI Tasikmalaya, Jawa Barat (PSIK BPK, 2002).

Desa Panjalu memiliki 3.044 orang kepala keluarga, dengan mata pencaharian utama sebagai pedagang, petani dan buruh baik buruh perkebunan, buruh industri dan buruh bangunan.Walaupun Desa Panjalu memiliki Situ Panjalu akan tetapi tidak ada satu orangpun warga Desa Panjalu yang tercatat dalam monografi desa berprofesi sebagai nelayan (Monografi Desa Panjalu, 2009). Hal ini dikarenakan pemanfaatan Situ Panjalu oleh masyarakat Desa Panjalu lebih ke sektor pariwisata khususnya wisata alam (Cagar Alam Nusa Gede) dan wisata budaya (ziarah). Melalui sektor wisata ini masyarakat mendapatkan penghasilan dengan berdagang dan menyewakan perahu. Pemanfaatan sumber daya alam di sektor perikanan hanya merupakan profesi sampingan untuk mendapatkan penghasilan tambahan. Namun jika dilihat dari kondisi geografis Desa Panjalu yang terletak di pegunungan dengan kondisi tanah yang subur; serta seiring dengan kemajuan bidang transportasi dan komunikasi yang disertai dengan peningkatan kemampuan penduduk dibidang pendidikan, maka terdapat perubahan orientasi mata pencaharian penduduk, terjadi pergeseran mata pencaharian dari pertanian ke arah perdagangan, transportasi dan jasa untuk memanfaatkan potensi wisata di Desa Panjalu.

Masyarakat Desa Panjalu dikenal sangat menjaga budaya warisan dari Kerajaan Panjalu. Salah satu budaya yang dilestarikan adalah upacara adat nyangku yang dilaksanakan setiap tahunnya. Upacara adat nyangku dilakukan untuk merawat benda-benda 
pusaka peninggalan Kerajaan Panjalu seperti pedang, cis, kujang, keris dan benda-benda pusaka lainnya, yang masih tersimpan baik di Museum Bumi Alit di dekat Alun-Alun Desa Panjalu. Jika ditinjau dari aspek sejarah, warga Desa Panjalu merupakan satu keturunan yaitu keturunan Kerajaan Panjalu. Pada saat pelaksanaan upacara adat nyangku, masyarakat desa meninggalkan akivitas kesehariannya. Penyelenggaraan upacara adat nyangku dilaksanakan oleh para sesepuh Panjalu, pemerintah desa, instansi-instansi terkait, tokoh masyarakat dan para Kuncen (juru kunci yang dianggap paling tahu mengenai adat tersebut). Jalannya upacara adat nyangku dikoordinir oleh Yayasan Borosngora ${ }^{1}$ dan pemerintah desa.

Upacara adat Nyangku menurut masyarakat di wilayah tersebut di artikan sebagai Nyangan Laku (menerangi perilaku), mengandung makna bahwa manusia harus dapat menjadi penerang hidup dan mampu menerangi hidup keluarga dan orang lain; sedangkan kegiatan menyucikan benda-benda pusaka peninggalan kerajaan Panjalu dilakukan untuk menghormati para leluhur, dan mengandung makna bahwa manusia harus selalu mensucikan niat, selalu membersihkan diri lahir dan bathin, dan selalu terbuka dengan perubahan yang ada.

Pola pandang masyarakat di wilayah ini menyikapi hakekat hidup, karya, waktu dan lingkungan sosial, sangat erat kaitannya dengan tingkat pendidikan yang dimiliki. Secara umum, tingkat pendidikan masyarakat di Situ Panjalu masih tergolong rendah dan hanya sampai jenjang sekolah dasar. Hal tersebut mempengaruhi pola pandang dan perilaku mereka pada kehidupan sehariharinya. Pandangan masyarakat tentang hidup, dilandasi oleh keadaan hidup yang penuh keterbatasan dan seadanya. Hal itu, membuat sebagian besar masyarakat berpandangan bahwa keterbatasan yang dimilikinya merupakan sesuatu yang tetap harus disyukuri dan perlu ditingkatkan menuju lebih baik lagi. Sebagian besar penduduk Situ Panjalu menganggap bahwa hidup pada hakekatnya adalah buruk, dan sesuatu yang buruk itu harus ditingkatkan menjadi lebih baik.

Kesederhanaan pola pikir mengenai hidup, dan jenjang pendidikan yang rendah sejalan dengan pernghargaan terhadap suatu karya. Sebagian besar masyarakat bekerja untuk memenuhi kebutuhan hidup, berkarya untuk tercapainya tujuan hidup.

Pandangan masyarakat dalam proses pemanfaatan waktu, sangat menggambarkan pola hidup yang pasif, dan berorientasi pada masa kini. Pemanfaatan waktu belum dilakukan secara maksimal oleh masyarakat untuk mengangkat derajat hidup.
Pola pandang masyarakat Situ Panjalu pada alam sangat beragam. Sebagian masyarakat berpandangan bahwa alam adalah sumber kehidupan sehingga alam harus dimanfaatkan sebaik mungkin. Apabila ketersediaan sumber kehidupan habis atau terjadi gangguan, maka mereka hanya bisa pasrah dan menunggu alam pulih dan dapat dimanfaatkan lagi. Sementara itu, kelompok lainnya berpendapat bahwa alam memiliki peran sebagai fasilitas hidup. Hal itu membuat pola pikir yang kreatif dan tidak pasrah pada alam. Oleh karena itu, mereka berusaha menguasai alam agar alam tetap dapat dimanfaatkan dalam kondisi apa pun.

Pengaruh dari keturunan Prabu Sang hyang Borosngora dalam kebijakan pemerintahan Desa Panjalu terlihat dari adanya hubungan kepengurusan Desa Panjalu dengan Yayasan Borosngora, dimana kebijakan-kebijakan yang dibuat oleh pemerintah desa harus sejalan dengan perizinan yayasan, mengingat kepengurusan Yayasan Borosngora dipimpin oleh tokoh masyarakat Desa Panjalu yang merupakan keturunan Raja Panjalu. Kebijakan-kebijakan yang di buat oleh tokoh masyarakat desa akan dipatuhi dan dianggap keputusan terbaik bagi kehidupan mereka, karena masyarakat Desa Panjalu memiliki pandangan tentang hakekat lingkungan sosial dengan berorientasi kepada atasan. Mereka berpendapat bahwa kehidupan bermasyarakat harus saling menolong, bergotong royong dan memberi manfaat satu sama lain. Hal yang menyangkut kepentingan bersama harus didahulukan dan di atas kepentingan pribadi.

\section{Pemanfaatan Sumber Daya dan Kelembagaan}

Pemanfaatan sumber daya alam dan kelembagaan yang terdapat di wilayah Situ Panjalu masih terikat dengan unsur adat. Unsur adat dalam hal ini terkait dengan petuah-petuah leluhur sangat kuat dipegang masyarakat di sekitar Situ Panjalu, walaupun bentuknya informal dan tak tertulis. Berdasarkan informasi dari masyarakat, Situ Panjalu merupakan warisan dari leluhur untuk dimanfaatkan oleh masyarakat di sekitar Situ Panjalu. Masyarakat di sekitar Situ Panjalu memiliki sikap yang berbeda satu dengan yang lain untuk memaknai amanat leluhur tentang memanfaatkan Situ Panjalu. Kelompok pertama berpandangan konservatif, artinya memanfaatkan Situ Panjalu secara bebas. Mereka beranggapan Situ Panjalu adalah warisan leluhur yang sumber dayanya tidak akan habis, sehingga boleh dimanfaatkan hingga kapan pun. Kelompok masyarakat ini menyambut baik tidak adanya aturan yang mengatur proses penangkapan

${ }^{1}$ Yayasan yang dibentuk oleh keturunan Prabu Sanghyang Borosngora untuk menjaga adat dari kerajaan Panjalu 
ikan di Situ Panjalu. Kelompok kedua berpandangan lebih modern, yang mengartikan pemanfaatan situ dengan pemanfaatan secara optimal dengan kewajiban yang harus dilakukan untuk menjamin keberlanjutan sumber daya situ di masa yang akan datang. Kelompok ini menyambut baik, bahkan memperjuangkan lahirnya aturan tegas dan mengikat untuk pengelolaan perairan umum Situ Panjalu.

Pemanfaatan perairan Situ Panjalu untuk sektor perikanan pada saat ini didominasi oleh kegiatan penangkapan, dan sebagian kecil budidaya karamba jaring apung. Alat tangkap yang digunakan adalah jala tebar, sirib atau anco, jaring insang dan pancing atau jeujeur. Hasil tangkapan berupa ikan-ikan kecil seperti ikan nila, golsom, keril, betook, beunteur, sepat dan lainnya. Ikan hasil tangkapan ini sebagian besar hanya untuk konsumsi rumah tangga dan sebagian kecil lainnya diperdagangkan. Masyarakat Dusun Dukuh merupakan masyarakat yang paling dominan melakukan kegiatan penangkapan di situ Panjalu dengan menggunakan alat tangkap aktif, yaitu jala tebar. Sementara itu, masyarakat Dusun Banjarwaru dan Dusun Balandongan tidak menjadikan penangkapan ikan sebagai kegiatan utama mereka. Alat tangkap yang mereka gunakan hanya alat tangkap pasif yaitu Sirib. Meskipun kegiatan penangkapan bukan yang utama, namun jumlah sirib atau anco yang ada di kedua dusun tersebut sangat banyak dibandingkan populasi alat tangkap tersebut di Dusun Dukuh.

Pada saat ini, kondisi perairan Situ Panjalu telah mengalami penurunan produktivitas. Salah satu indikasinya adalah hasil tangkapan ikan semakin menurun dan hanya bisa dimanfaatkan untuk konsumsi rumah tangga sendiri. Penurunan produktivitas tersebut disebabkan oleh program pembersihan situ dari tanaman air untuk keperluan wisata serta adanya pembangunan jalan atau tanggul untuk keperluan wisata kereta kuda, hal ini diperkirakan memberikan dampak pada hilangnya nursery ground di tepian Situ.

Penurunan produktivitas perairan Situ Panjalu telah mengurangi minat warga untuk menangkap ikan di wilayah tersebut. Saat ini, hanya sekitar 20 (dua puluh) orang warga saja yang masih melakukan penangkapan dengan menggunakan jala tebar dan gill net. Walaupun banyak terlihat alat tangkap anco di tepian Situ Panjalu, meskipun produktivitas alat tangkap tersebut dianggap sangat kecil, sehingga penggunaan anco hanya dilakukan oleh pemiliknya saat waktu senggang saja.

Pemanfaatan Situ Panjalu untuk pariwisata telah berkembang pesat. Kondisi sarana transportasi menuju Desa Panjalu yang semakin baik membuat jumlah pengunjung lokasi wisata meningkat. Jumlah wisatawan sekitar 6000 jemaah setiap hari berkunjung ke Nusa Gede untuk berziarah. Hal ini dimanfaatkan oleh warga untuk menyediakan jasa penyewaan perahu, penjualan cindera mata, rumah makan dan penginapan.
Meskipun hingga saat penelitian dilakukan, pengaturan pengelolaan perairan situ Panjalu masih sebatas himbauan dan seruan dari aparatur pemerintahan desa, belum ada aturan secara formal dan tertulis. Himbauan tersebut terkait larangan menangkap ikan berukuran kecil, larangan menggunakan alat tangkap dengan mesh size kurang dari 1 (satu) inchi dan larangan menangkap ikan di kawasan tutupan atau kawasan restocking. Meskipun himbauan yang dikeluarkan oleh aparatur pemerintahan desa tidak diikuti oleh pengawasan yang ketat, sehingga mengakibatkan himbauan tersebut tidak semuanya dipatuhi oleh masyarakat.

Ditinjau dari aspek kelembagaan, masyarakat di sekitar Situ Panjalu tidak memiliki kelembagaan yang khusus untuk menaungi pengelolaan sumber daya perairan, akibatnya pengelolaan dan kontrol pengawasan dibebankan pada aparatur pemerintahan desa dan kampung serta kesadaran masyarakat Situ Panjalu itu sendiri. Di wilayah Dusun Banjarwaru, Desa Situ Panjalu, pernah dibentuk kelompok perkumpulan warga Banjarwaru, yang dibentuk untuk mengatur masalah penangkapan ikan, meskipun perannya tidak berlanjut sampai saat ini. Perkumpulan perahu di kawasan wisata di wilayah ini terdapat 2 (dua) organisasi yang mengatur, pertama, Dayung Sampan Club (DSC), beranggotakan 21 orang, mengatur kegiatan perahu dayung di kawasan wisata, termasuk mengatur jadwal, harga dan aktivitas para ojek perahu dayung ini. Kedua,organisasi Perahu Motor Group (PMG), mempunyai 11 orang anggota dan merupakan perkumpulan para ojek perahu motor. Paguyuban Kawula Muda Cukang padung, yang merupakan lembaga atau perkumpulan pemuda, yang mengatur pengelolaan situ terkait pariwisata. Biasanya lembaga ini mengatur tata letak dan perizinan aktivitas dagang di kawasan wisata situ dan program pembersihan situ. Anggota lembaga ini terdiri dari pemuda dan warga masyarakat daerah kampung kawasan wisata yaitu Kampung Cukang Padung.

Implikasi ketiadaan aturan dan kelembagaan khusus membuat masyarakat bebas menangkap ikan dengan menggunakan berbagai jenis alat tangkap dan ukuran ikan. Masyarakat berdalih tidak akan melanggar peraturan, mengingat belum ada aturan atau lembaga yang mengatur pengelolaan perairan Situ Panjalu.

\section{Pengelolaan Situ Panjalu}

Permasalahan utama dalam pengelolaan Situ Panjalu adalah tidak adanya aturan yang tegas, mengikat dan formal, ketiadaan lembaga khusus yang mengatur pengelolaan perairan, dan produktivitas perairan yang randah serta kurangnya kesadaran dan pemahaman dalam melakukan pemanfaatan perairan yang berkelanjutan. Saat ini, kontrol yang berlaku pada pengelolaan perairan Situ Panjalu hanya tergantung pada kesadaran masyarakat. Kontrol ini memiliki nilai 
ketegasan yang sangat rendah, karena sanksi yang berlaku hanya peneguran dari sesama warga. Pola pandang sebagian masyarakat di sekitar Situ Panjalu, berorientasi pada pimpinan dengan tetap memelihara jiwa gotong royong. Sikap dasar ini dapat menjadi pijakan, untuk pembuatan aturan yang tegas dan formal, dan menjadikan aturan yang dibuat lebih terjamin kepatuhan pada saat pelaksanaannya di masyarakat.

Keberadaan kelembagaan khusus penting untuk pengelolaan Situ Panjalu. Lembaga khusus pengelolaan perairan Situ Panjalu akan menjadi wadah kegiatan seluruh masyarakat Situ Panjalu terkait pengelolaan perairan, dan sekaligus menjadi pengawas bagi pelaksanaan aturan yang diberlakukan. Kelembagaan yang ada seharusnya menaungi seluruh wilayah di sekitar situ panjalu dan kepengurusannya merupakan perwakilan-perwakilan dari tiap dusun di sekitar situ Panjalu. Asas keterwakilan ini diharapkan menjadi pemersatu setiap wilayah yang bersama-sama mengelola Situ Panjalu.se

Rendahnya produktivitas perairan di Situ Panjalu disebabkan tingkat penangkapan ikan tidak sebanding dengan kecepatan regenerasi ikan yang terdapat di Situ Panjalu. Adanya inisiasi dari sebagian warga yang mendukung pemulihan situ melalui penebaran kembali ikan dan pelarangan penangkapan ikan sampai jangka waktu tertentu di wilayah penebaran, dapat menjadi dorongan besar bagi proses peningkatan produktivitas perairan Situ Panjalu. Saat ini, dukungan pemerintah setempat melalui kebijakan atau aturan yang tegas diperlukan untuk merealisasikan pengelolaan Situ Panjalu secara berkelanjutan. Selain itu, untuk menghindari terjadinya pelanggaran-pelanggaran, perlu dilakukan diseminasi kegiatan atau mata pencaharian, sehingga masyarakat tidak tergantung sepenuhnya pada Situ Panjalu.

\section{KESIMPULAN DAN REKOMENDASI KEBIJAKAN}

\section{Kesimpulan}

Peran masyarakat Desa Panjalu dalam pengelolaan perairan Situ Panjalu masih sebatas pemanfaatan secara sepihak, sementara kontribusi masyarakat terhadap Situ Panjalu masih sangat rendah. Hal tersebut dikarenakan belum adanya aturan yang jelas mengenai pengelolaan situ, dan tidak adanya lembaga khusus yang mewadahi pengelolaan dan pengawasan aturan di situ Panjalu. Potensi sifat kooperatif dan inisiasi pengelolaan berkelanjutan dari sebagian besar masyarakat di sekitar Situ Panjalu, merupakan langkah awal untuk pengelolaan Situ Panjalu yang lebih baik dan berkelanjutan. Situ Panjalu merupakan kawasan yang memiliki potensi pemanfaatan untuk kesejahteraan masyarakat. Pengelolaan berkelanjutan untuk sumber daya alam yang ideal adalah dilakukan secara terpadu antara masyarakat dan pemerintah setempat. Oleh karena itu, diperlukan suatu lembaga yang mengatur pemanfaatan dan pengelolaan Situ Panjalu khususnya dalam sektor perikanan.

\section{Rekomendasi Kebijakan}

Berdasarkan pada uraian tersebut diatas, pengelolaan sumber daya berbasis masyarakat dengan dukungan pemerintah merupakan rekomendasi kebijakan yang dapat dilakukan secara bersama, mengingat keberlanjutan pemanfaatan suatu sumber daya amat tergantung pada kebijakan pengelolaan sumber daya tersebut.

\section{DAFTAR PUSTAKA}

Balai Besar Riset Sosial Ekonomi Kelautan dan Perikanan (BBRSEKP). 2010 Laporan Teknis Penelitian Peran Masyarakat Adat Dalam Pengelolaan Sumber Daya Perikanan Perairan Umum. Jakarta: BBRSEKP, 2010. Unpublished.

Pemerintah Kabupaten Ciamis Kecamatan Panjalu Desa Panjalu, 2009.Monografi Desa Panjalu Kecamatan Panjalu Kabupaten Ciamis. $19 \mathrm{hlm}$

Soemarwoto, O. 1997. Ekologi, Lingkungan Hidup, dan Pembangunan. Jakarta: Djambatan, 1997. 381 hlm.

Sugandhy, A. 1999. Penataan Ruang dan Pengelolaan Lingkungan Hidup. Jakarta: PT Gramedia Pustaka Utama, 1999. $292 \mathrm{hlm}$.

Pusat Inventarisasi dan Statistik Kehutanan Badan Planologi Kehutanan (PISK BPK). 2002. Data dan Informasi Kehutanan Propinsi Jawa Barat. Jakarta: PISK BPK, 2002. 25 hlm. 